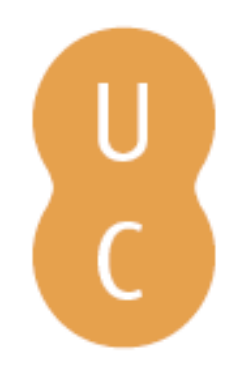

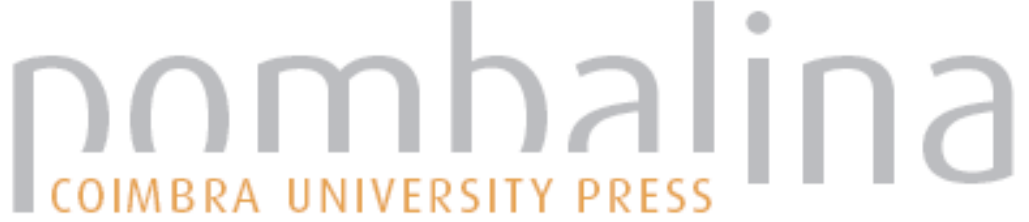

\section{A experiência liberal-democrática no Brasil (1946-1964): revisitando temas historiográficos}

\author{
Autor(es): $\quad$ Ferreira, Jorge \\ Publicado por: Imprensa da Universidade de Coimbra \\ URL \\ persistente: URI:http://hdl.handle.net/10316.2/38577 \\ DOI: $\quad$ DOI:http://dx.doi.org/10.14195/978-989-26-0646-0_6 \\ Accessed : $\quad$ 26-Apr-2023 12:14:33
}

A navegação consulta e descarregamento dos títulos inseridos nas Bibliotecas Digitais UC Digitalis, UC Pombalina e UC Impactum, pressupõem a aceitação plena e sem reservas dos Termos e Condições de Uso destas Bibliotecas Digitais, disponíveis em https://digitalis.uc.pt/pt-pt/termos.

Conforme exposto nos referidos Termos e Condições de Uso, o descarregamento de títulos de acesso restrito requer uma licença válida de autorização devendo o utilizador aceder ao(s) documento(s) a partir de um endereço de IP da instituição detentora da supramencionada licença.

Ao utilizador é apenas permitido o descarregamento para uso pessoal, pelo que o emprego do(s) título(s) descarregado(s) para outro fim, designadamente comercial, carece de autorização do respetivo autor ou editor da obra.

Na medida em que todas as obras da UC Digitalis se encontram protegidas pelo Código do Direito de Autor e Direitos Conexos e demais legislação aplicável, toda a cópia, parcial ou total, deste documento, nos casos em que é legalmente admitida, deverá conter ou fazer-se acompanhar por este aviso.

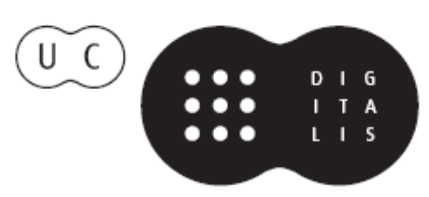




\section{A EXPERIÊNCIA LIBERAL-DEMOCRÁTICA NO BRASIL (1946-1964): REVISITANDO TEMAS HISTORIOGRÁFICOS}

JORGE FERREIRA ${ }^{1}$

A historiografia brasileira encontra-se em estágios de profissionalização bastante avançados, sobretudo nos estudos coloniais e do século XIX. Durante muitos anos, a desconfiança existente em estudar temporalidades mais próximas criou resistências para a pesquisa de temas contemporâneos. A partir dos anos 1970, mas sobretudo na década 1980, as resistências começaram a ser vencidas, surgindo pesquisas sobre a Primeira República (1889-1930) e o primeiro período de governo de Getúlio Vargas (1930-1945). Mais recentemente, nas áreas da História, da Sociologia, da Antropologia e da Ciência Política, pesquisadores se dedicam a temas relativos à ditadura militar.

Os historiadores, no entanto, parecem não demonstrar interesses sobre a temporalidade que se abre em 1946 e se encerra em 1964. Em comparação a outros períodos, pesquisas sobre aquela experiência liberal-democrática ficaram reservadas para os pesquisadores da Ciência Política e da Sociologia.

Não é meu objetivo delimitar rigidamente áreas de atuação nas Ciências Humanas. No Brasil, economistas, cientistas políticos e sociólogos têm realizado trabalhos de excelência na área de História. Mas o que chama a atenção é que são os cientistas políticos e sociólogos aqueles que, majoritariamente,

${ }^{1}$ Professor Titular de História do Brasil da Universidade Federal Fluminense, Pesquisador I do CNPq e da FAPERJ. 
produziram trabalhos que se tornaram clássicos sobre a experiência democrática brasileira.

O meu objetivo é, em primeiro lugar, discutir algumas questões sobre o estatuto político do regime; em segundo, comentar dois temas historiográficos considerados básicos sobre o período: os partidos políticos e o golpe civilmilitar de 1964.

\section{A experiência política brasileira pós 1945: um projeto liberal-democrático}

O Brasil inaugurou sua experiência democrática em 1946 com uma Assembléia Nacional Constituinte, livremente eleita pela população e politicamente soberana. Nela estavam representados diversos setores da sociedade brasileira, de liberais a comunistas. Embora sob forte influência dos valores liberais-democráticos do período imediatamente posterior à Segunda Guerra Mundial e com o repúdio ao autoritarismo do Estado Novo, os constituintes mantiveram alguns dispositivos implementados nos anos 1930. Evitaram o retorno à excessiva descentralização política da Primeira República e permitiram que o Executivo mantivesse suas prerrogativas ampliadas. Conservaram a legislação corporativista, reconhecendo que o modelo apresentava certo grau de consenso na sociedade e de apoio no movimento sindical. O pluralismo partidário, portanto, passou a coexistir com a unicidade sindical. Os constituintes estavam afinados com os ventos liberais-democráticos que vinham da Europa e dos Estados Unidos, mas não desconheceram as experiências vividas no próprio Brasil nos anos 1930. O resultado foi uma Constituição que sustentou a democracia-liberal, implantada, pela primeira vez, no Brasil.

As dificuldades para viabilizar o regime democrático no Brasil devem ter sido imensas. Afinal, os antecedentes conhecidos eram o autoritarismo dos anos 1930 e o liberalismo excludente da Primeira República. Até então, a sociedade brasileira não conhecera experiências de participação política ampliada.

Com a Constituição de 1946, a sociedade brasileira teve acesso aos direitos políticos. Na década de 1930, os assalariados, em particular, tiveram outro importante aprendizado: o exercício dos direitos sociais, sobretudo com as leis trabalhistas. É possível afirmar que o aprendizado de cidadania social já estava consolidado 
em fins de 1945. O momento que se abria para a sociedade brasileira era de outra dimensão: aprender a lidar com os direitos políticos e a exercer os direitos civis.

Surgiram partidos políticos nacionais, com programas ideológicos definidos e identificados com o eleitorado; as eleições tornaram-se sistemáticas e periódicas para os cargos do Executivo e do Legislativo nos planos federal, estadual e municipal. Com base no sufrágio universal e com alto grau de competitividade, as eleições eram fiscalizadas pela Justiça Eleitoral.

No entanto, segundo José Murilo de Carvalho, são grandes as dificuldades em admitir que, naquela época, a sociedade brasileira conheceu sua “primeira experiência democrática” (CARVALHO, 2004:127).

\section{Um regime democrático?}

Muitos historiadores negam o caráter democrático do regime instaurado em 1946. Em geral dois argumentos são muito utilizados, particularmente pela historiografia marxista.

O primeiro é que no governo de Eurico Dutra o Partido Comunista (PCB) foi posto na ilegalidade, enquanto seus militantes sofreram perseguições e o movimento operário foi cerceado pelo aparato policial repressivo. De fato, um ano após a promulgação da nova Constituição, em 1947, as relações internacionais foram alteradas profundamente com o clima beligerante da Guerra Fria. O Brasil não ficou imune aos conflitos entre Estados Unidos e União Soviética e, em vários setores da sociedade, despontou o sentimento anticomunista. O PCB teve seu registro cassado e forte repressão se abateu sobre o movimento sindical.

Mas devemos perguntar se, na mesma época, foi diferente na maior democracia ocidental, os Estados Unidos, em que atuavam os comitês de atividades antiamericanas, o macarthismo; as listras negras de artistas e intelectuais, a lei Taft-Hartley ${ }^{2}$ e o Communist Control Act, ${ }^{3}$ bem como o FBI intrometendo-se

\footnotetext{
2 O Congresso norte-americano, em 1947, aprovou a lei Taft-Hartley, tornando ilegais determinadas greves e limitando a representação sindical no país.

3 O Congresso dos Estados Unidos aprovou, em 1954, o Comunist Control Act, legislação que criminalizava atividades consideradas comunistas.
} 
na vida privada dos cidadãos. Todo esse conjunto de medidas acuaram as esquerdas e o movimento sindical daquele país, alimentando a histeria anticomunista. Nos Estados Unidos e na Alemanha (antiga Ocidental), os partidos comunistas também foram declarados ilegais - e nem por isso tais países foram denunciados como "não-democráticas".

Em outro aspecto, é preciso considerar que existiram alterações e ritmos variados nas relações entre Estado e o movimento comunista no Brasil. Se durante o governo Dutra a repressão policial aos militantes revolucionários foi violenta, em 1951, João Goulart, na presidência do PTB, avalizou aliança entre os trabalhistas e os comunistas no plano sindical. Em sua gestão no Ministério do Trabalho, dois anos depois, os pecebistas assumiram a direção de sindicatos sem perseguições ou empecilhos legais. Durante os governos de Juscelino Kubitschek e João Goulart, eles agiram livremente, em situação de semi-legalidade.

Outro argumento para desqualificar o caráter democrático do regime é a interdição do direito de votar dos analfabetos. Como no caso dos comunistas, sem dúvida que se tratou de uma limitação das prerrogativas democráticas. Contudo, é preciso considerar a ampliação do direito ao voto no Brasil nessa época. Segundo o sociólogo Gláucio Ary Dillon Soares, o regime da Carta de 1946 teve como principal êxito a ampliação dos direitos de cidadania política. $\mathrm{Na}$ primeira eleição, a de dezembro de 1945, votaram cerca de 7,5 milhões de pessoas, contra 1,5 milhão no pleito de 1933. Ao longo dos anos, o alistamento eleitoral não parou de crescer, chegando a 18,5 milhões de cidadãos votando em 1962 - duas vezes e meia comparando a 1945 e 12 vezes a mais que 1933. No caso das eleições presidenciais, o número de participantes dobrou: de 6 milhões de votantes na primeira eleição para presidente, alcançou 12 milhões em 1960 (SOARES, 2001:313).

O crescimento do número de votantes foi devido à expansão do sistema educacional: os analfabetos eram 54\% em 1945 e passaram para 36\% em 1962. Além disso, o número de novos eleitores foi maior que o aumento da população. "O aumento de 11 milhões de eleitores mostra que a cidadania se ampliou gradualmente, democratizando o eleitorado”, afirma Gláucio Ary Dillon Soares. Além disso, continua o mesmo autor, "outro impacto positivo para a democracia foi inculcar na cultura brasileira o valor do voto, divulgando a 
idéia de que votar era bom e um direito ao qual amplos setores da população também deveriam ter acesso" (SOARES, 2001:318).

A desqualificação do regime democrático de 1946 tomou força com o golpe civil-militar que, em março de 1964 encerrou aquela experiência (AARÃO REIS, 2001). O conjunto de forças políticas que apoiou o golpe de Estado e sustentou a ditadura formulou uma série de imagens desqualificadoras sobre o período, a exemplo da corrupção, da incompetência e da demagogia. Para as "direitas", haveria no país um povo "ingênuo" e destituído de "cultura" política e, por isso, facilmente manipulado por líderes políticos inescrupulosos. Mas setores das "esquerdas” também elaboraram representações igualmente demeritórias, sobretudo no tocante à manipulação dos operários por lideranças exteriores à classe, a exemplo de políticos reformistas e sindicalistas "pelegos". Para as "direitas", inexistiria o cidadão cônscio de seus direitos, enquanto para as "esquerdas" os operários ainda não estariam conscientes de seus "verdadeiros" interesses de classe. Ao lado das "direitas" e das "esquerdas", intelectuais e imprensa também colaboraram para a imagem negativa que se formava. Criou-se, assim, um conjunto de imagens e representações que se firmou no imaginário acadêmico brasileiro durante muitos anos: as dificuldades da sociedade brasileira em conviver com instituições democráticas e que, no limite, resultaram no fracasso da experiência liberal-democrática no Brasil.

O pouco interesse dos historiadores pelo período e as imagens fortemente introjetadas no imaginário acadêmico que desqualificavam o período resultaram na caracterização das instituições liberais-democráticas e republicanas - incluindo o movimento sindical - como populistas. Durante muitos anos, a experiência democrática que se abriu em 1945 com o fim do Estado Novo e se encerrou com o golpe civil-militar de 1964 ficou conhecida por categorias pejorativas como período populista, república populista ou democracia populista. As expressões podem ser encontradas tanto em livros didáticos quanto em textos produzidos nas universidades. Nesse sentido, a contribuição de Francisco Weffort em textos publicados nos anos 1960 e reunidos no livro $O$ populismo na política brasileira, de 1978, é chave para a compreensão desse processo (WEFFORT, 1978).

Mesmo que superadas por pesquisas mais recentes, as teses tradicionais ainda são bastante aceitas. É o caso dos textos que afirmam o caráter artificial 
do sistema partidário, de pouco enraizamento na sociedade, sem consistência ideológica e ainda dominado por lideranças carismáticas; ou do "corporativismo" e da Consolidação das Leis do Trabalho (CLT) que teriam desviado a classe operária de seus "verdadeiros" interesses, formalizando a "tutela" do Estado sobre os trabalhadores. Outras teses falam do "agrarismo", do "clientelismo" e da "tradição escravista do trabalho". Algumas referem-se ao "patrimonialismo do Estado". As instituições, por sua vez, seriam pouco representativas, tendo como exemplo o Congresso Nacional, ora visto como "reacionário e ineficiente", ora definido como reflexo dos interesses econômicos privados. O clientelismo, o corporativismo, o populismo e outras mazelas da política brasileira resultariam dos vínculos formados entre instituições frágeis, um Estado forte e uma sociedade incapaz de se manifestar (GOMES, 1998: 542-543). Os estudos marcados pelo determinismo econômico complementam o quadro de desqualificação da experiência liberal-democrática no Brasil, sugerindo a incompatibilidade da sociedade brasileira com aquelas instituições.

Uma das imagens que mais desmereceram a sociedade brasileira daquele época foi, sem dúvida, a do populismo. Diversos pesquisadores, atualmente, criticam a expressão por sua excessiva generalização. Por sua elasticidade, o termo populismo se esforça por dar conta de personagens de diferentes tradições políticas sob as mesmas características. Desse modo, importantes projetos políticos que mobilizaram a sociedade perdem suas especificidades. Obra coletiva que avalia criticamente o conceito foi organizado pelo autor desse texto com o título O populismo e sua história, debate e crítica (FERREIRA, 2001). Nele, principalmente eu, Angela de Castro Gomes e Daniel Aarão Reis reconstituímos a história do conceito e criticamos seus fundamente, negando sua eficácia para explicar a história política brasileira.

As desqualificações, portanto, são múltiplas. Em termos gerais, muitos estudos na área de História apresentam dificuldades de reconhecer a importância dos direitos civis e de valorizar os direitos políticos nos regimes liberaisdemocráticos, preferindo centrar as análises nos mecanismos de controle, dominação e coerção social.

Os que resistem em admitir que o período representou uma experiência democrática, pensando no governo Dutra, na cassação do registro do PCB e na interdição dos analfabetos ao direito de votar, baseiam-se, muitas vezes, 
em uma receita prévia de democracia, não considerando que esta não surge pronta, como um receituário, mas é conquistada, ampliada e "inventada", no dizer de Claude Lefort. A democracia não se encontra em lugar determinado no horizonte, tal qual o pote de ouro na ponta do arco-íris, mas resulta de demandas da própria sociedade, de seus conflitos e contradições, inventando e reinventando práticas e instituições democráticas. A democracia é um processo marcado pela incompletude, avançando de acordo com as demandas dos cidadãos e dos grupos sociais que dela participam - e reivindicam.

\section{O sistema partidário na experiência democrática}

O objetivo, nesse momento, é explorar obras consideradas referências obrigatórias para o estudo dos três grandes partidos que dominaram o cenário político-eleitoral brasileira durante a experiência democrática - a UND, o PSD e o PTB. Nesse sentido, partidos de menor expressão eleitoral ${ }^{4}$ e o Partido Comunista Brasileiro não serão tratados ao longo da exposição. ${ }^{5}$

Maria do Carmo Campello de Souza publicou, em 1976, livro considerado pioneiro na análise do sistema partidário pós-1945: Estado e partidos políticos no Brasil (1930-1964). Resultado de sua tese de

${ }^{4}$ No caso desses partidos políticos, vale citar os seguintes trabalhos: BASTOS, Suely. "A cisão do MTR com o PTB». In FLEISCHER, David (org.). Partidos políticos no Brasil. Brasília, Editora da UNB, vol. 1, 1981; COELHO, Sandro Anselmo. O Partido Democrata Cristão: teores programáticos da terceira via brasileira (1945-1964). Revista Brasileira de História. Vol. 23, n. 46, 2003; GUSTIN, Miracy Barbosa de Sousa e VIEIRA, Margarida Luiza de Matos. Semeando democracia: a trajetória do Partido Socialista Brasileiro. Contagem, Palesa, 1995; HECKER, Alexandre. Propostas de esquerda para um novo Brasil: o ideário socialista do pós-guerra. In FERREIRA, Jorge e AARÃO REIS, Daniel (orgs.). Nacionalismo e reformismo radical (19451964). As esquerdas no Brasil, volume 2. Rio de Janeiro, Civilização Brasileira, 2007; SAMPAIO, Regina. Adhemar de Barros e o PSP. São Paulo, Global, 1982.

5 A produção bibliográfica sobre o Partido Comunista é extensa. Sem dúvida, o PCB foi o partido político mais estudado no Brasil. A bibliografia é vasta seja na primeira década de sua existência nos anos 1920, nos episódios que culminaram com a insurreição de 1935, nos anos de vida legal e, sobretudo, na década de 1950, a partir de radicalização com o Manifesto de Agosto de 1950. De maneira sintomática, os estudos sobre o PCB diminuem sensivelmente após 1958, período regido pelo documento conhecido como Declaração de Março, emitido naquele ano. 
doutoramento em Ciência Política na Universidade de São Paulo, a tese central da autora é a de que a vida partidária e eleitoral brasileira durante a experiência liberal-democrática foi constituída sob os alicerces do regime getulista, em transição política destituída de rupturas marcantes. Para autora, durante os anos do Estado Novo foram instituídos aparatos "jurídicos-institucionais e políticos bastante complexos, destinados a viabilizar o controle do poder central sobre as esferas estratégicas da economia (...). O desmantelamento da velha ordem não ultrapassou os limites da 'modernização conservadora': sem qualquer reformulação radical da estrutura sócioeconômica existente encaixavam-se no sistema político novos grupos de interesses, devidamente cooptados e burocratizados" (SOUZA, 1976: 95). Basta citar a máquina política herdada dos interventores do Estado Novo, o poder burocrático de Estado, como os institutos, autarquias, grupos técnicos e, particularmente, o Departamento Administrativo do Serviço Público (DASP), e o próprio papel político das Forças Armadas.

Segundo a autora, a elite política que dirigiu o país entre 1930 e 1945 continuou no poder após a saída de Getúlio Vargas do poder. A Constituição de 1946, redigida por essas mesmas elites, manteve vários dispositivos criados no período autoritário anterior. Assim, as instituições da democracia-liberal (eleições livres, pluralismo político, divisão dos Poderes da República, etc.) conviveram com o sindicalismo corporativista e com a burocracia estatal com grande capacidade decisória.

Outra questão importante levantada por Marcia do Carmo Campello de Souza é que o regime democrático herdou do período anterior a ideologia anti-partidária, típica dos anos 1930, formulada tanto por intelectuais de esquerdas quanto de direita. Para os ideólogos antiliberais dos anos 1930, inclusive os que apoiavam o Estado Novo, os partidos e o parlamento eram artificiais, corrompidos, sem representatividade. Para Campello de Souza, "o advento do pluralismo partidário, das eleições diretas, e o retorno à separação formal dos poderes do Estado, determinados pela Carta de 1946, foram superpostos ou acoplados à estrutura anterior, marcada pelo sistema de interventorias, por um arcabouço sindical corporativista, pela presença de uma burocracia estatal detentora de importante capacidade decisória, para não mencionarmos a plena vigência (...) de uma ideologia autoritária de Estado" (SOUZA, 1976: 105-106). 
Contudo, Maria do Carmo Campello de Souza não nega a instituição do regime democrático no país com o fim do Estado Novo. Embora o processo de transição democrática não foi mais radicalizado do que poderia ter sido, mesmo com todos os problemas o sistema partidário pós-1945, afirma a autora, foi constituído por organizações legítimas que expressaram os diversos interesses e ideologias que circulavam na sociedade. À medida que o país se urbanizava e se modernizava, os partidos políticos tornam-se instrumentos da participação popular. Para Campello de Souza, o sistema partidário brasileiro do período democrático não surgiu, em 1945, condenado à inviabilidade, mas apontava para a transição a um quadro eleitoral representativo que poderia superar as ideologias autoritárias e o poder burocrático estatal.

A UDN e o udenismo. Ambigüidades do liberalismo brasileiro (1945-1965), de Maria Victoria de Mesquita Benevides, livro publicado em 1981, é resultado de sua tese de doutoramento em Ciências Sociais na Universidade de São Paulo no ano anterior. Trata-se, ainda, do trabalho mais importante sobre a UDN produzido no Brasil. ${ }^{6}$

O partido surgiu como um movimento contra o Estado Novo. No contexto de 1945, indivíduos ou grupos políticos e sociais que se opunham a Vargas e apoiavam a candidatura do brigadeiro Eduardo Gomes à presidência da República tinham na UDN o seu lugar na política. Ao longo de sua trajetória política na experiência democrática brasileira, a UDN foi identificada em diversas análises como um "partido das classes médias". Para Benevides, a UDN assim podia ser considerada porque era o único grande partido político que se dirigia diretamente às classes médias, denunciando, sobretudo, a corrupção administrativa e os perigos de "proletarização". Contudo, em termos de defesa dos interesses econômicos, o partido expressava as demandas dos grandes proprietários de terras e dos industriais aliados ao capital estrangeiro (BENEVIDES, 1981: 217).

Maria Victória Benevides, na primeira parte do livro, trabalha com a trajetória da UND do ponto de vista histórico, mas, na segunda parte, explora o que define como udenismo, determinada apropriação do liberalismo

${ }^{6}$ Livro que deve ser incluído nas referência sobre o tema é o de DULCI, Otávio. A UDN e o anti-populismo no Brasil. Belo Horizonte, Ed. da UFMG, 1986. 
brasileiro após 1945. A autora entende o udenismo como um conjunto de práticas políticas e ideologias que extrapolavam os limites da própria UDN, embora identificada com o partido político.

Apesar de ressaltar que o udenismo não se reduz ao partido político, sendo mesmo anterior a ele, havia na expressão determinadas características que lhe davam certa coerência e homogeneidade. Entre eles estão o liberalismo restritivo à participação popular e a defesa da presciência das elites na prática política - resultando no elitismo como primeira característica do udenismo; o liberalismo econômico expresso em radical antiestatismo; o moralismo como meio de atacar o getulismo e atrair o eleitorado de classe média; o bacharelismo com a marca da retórica e da erudição jurídica; o anticomunismo; a desconfiança do movimento sindical; por fim, marca indelével do udenismo: o antigetulismo. Os diversos elementos estão presentes no partido, embora com magnitudes diferenciadas nas diversas alas que compunham a organização, a exemplo dos bacharéis defensores do liberalismo clássico conhecidos como "históricos", dos progressistas que se agrupavam na ala chamada de "Bossa Nova", da "Banda de Música", dos ortodoxos defensores do conservadorismo e do golpismo, da "UDN chapa-branca", com seus adeptos do fisiologismo, entre outras facções partidárias. O udenismo dos bacharéis certamente não era o mesmo da ala de extrema-direita do partido liderada por Carlos Lacerda.

Para Benevides, as "ambigüidades" do liberalismo brasileiro expresso na UDN e no udenismo era aceitar e participar do jogo democrático, mas negar a legitimidade dos resultados eleitorais, recorrendo ao recurso do golpe de Estado. O elitismo udenista era assumido de maneira ostensiva em duas práticas na trajetória do partido, segundo a autora: "a identificação de reivindicação sociais e, especificamente trabalhistas, com a desordem, 'o caos', e um solene desprezo pelo povo - 'as massas' - refletido na permanente revolta com a derrota nas urnas, considerada 'fruto da ignorância popular'. A soma desses dois elementos constituiria um sólido argumento para a defesa da intervenção militar e da própria repressão ao movimento operário (a 'anarquia e a subversão') por um lado, e do golpismo e da contestação dos resultados eleitorais, por outro" (BENEVIDES, 1981: 253).

Para a autora, entre o medo de aderir incondicionalmente ao regime democrático e a vergonha de defender o golpismo encontram-se sua incapacidade 
de formular um projeto de poder. O recurso ao golpe de Estado, tendo os militares à frente, resultava da crença de que o regime autoritário seria transitório, sobretudo necessário para alcançar o autêntico regime democrático. Diante das seguidas frustrações com as derrotas eleitorais, os udenistas alegavam a falta de amadurecimento do povo para o exercício da prática democrática, incapaz que era de eleger seus representantes. Essa era a origem da contestação dos resultados eleitorais e o apoio à intervenção dos militares no processo político (BENEVIDES, 1981: 249). Resumindo ao máximo a tese de Benevides, a definição da UDN é a seguinte: "a UDN é progressista no que se opõe, reacionária no que propõe" (BENEVIDES, 1981: 250).

Sobre o PSD, a obra de referência ainda é a de Lúcia Hippolito, De raposas e reformistas: o PSD e a experiência democrática brasileira (1945-64), livro publicado em 1985 e resultado de seu mestrado em Ciência Política no IUPERJ no ano anterior. ${ }^{7}$ Embora afirme não propor escrever a história do partido, objetivo considerado ambicioso, a autora realiza um trabalho minucioso da trajetória do PSD, das relações conflituosas entre os poderes Executivo e Legislativo no período, a importância das questões locais nas decisões do partido, o surgimento de um grupo de viés progressista conhecido como "Ala Moça" que disputava espaços com os conservadores denominados "raposas", entre diversas outras questões.

Seguindo de maneira criativa algumas indicações teóricas de Gionvani Sartori, Lúcia Hippolito define o PSD como partido "solidamente instalado no centro político" (HIPPOLITO, 1985:37). Essa é a tese central que defende no livro. Em um regime pluralista, o PSD foi o fiador da democracia-liberal brasileira. Os pessedistas deram o tom da moderação política, pelo menos até a virada dos anos 1950 para a década seguinte, tanto atuando pela negociação quanto pela "omissão preventiva”. Como diz a autora, a UDN esperneia, o PTB cresce, mas é o PSD que dá o tom.

Relevante no livro de Lucia Hippolito é demonstrar que embora o PSD

7 Lucia Hippolito reeditou o livro em 2012 pela editora Nova Fronteira. Sobre o PSD é importante citar, também, a dissertação de mestrado de Lucia Lippi Oliveira desenvolvida no IUPERJ em 1973. Algumas idéias defendidas na dissertação foram publicadas em OLIVEIRA, Lúcia Lippi. O Partido Social Democrático. In FLEISCHER, David. (org). Os Partidos Políticos no Brasil. Brasília, Editora UNB, vol I, 1981. 
tenha sido um partido fortemente centralizado, os poderes dos diretórios locais impediam imposições vindas de cima, havendo influências recíprocas entre ambas as instâncias decisórias. O processo ocorria porque o PSD encontrava seu vigor da prática eleitoral. Sua força vinha do voto para conquistar maiorias parlamentares e governos estaduais. Desse modo, o partido apostou no regime de democracia representativa e mesmo durante o processo de radicalização política em fins do governo Goulart, o PSD esforçou-se para defender o regime até o último momento, somente rompendo com o presidente em 10 de março de 1964, três dias antes do comício dia 13. Mesmo assim, o partido foi para a oposição - e não para a conspiração. Lucia Hippolito trabalha com algo difícil de ser compreendo no Brasil: um partido de perfil conservador defendia as instituições democráticas e tinha interesses políticos na manutenção da ordem legal. Segundo a autora, o PSD "jamais contribuiu para o rompimento da normalidade constitucional; em toda a sua história nunca o partido se afastou da observância da legalidade e da continuidade institucional" (HIPPOLITO, 1985:233).

Enquanto manteve-se à frente das iniciativas políticas, o sistema político brasileiro o acompanhou. Contudo, no início dos anos 1960, o sistema político brasileiro deslocou-se para a esquerda e o PSD não acompanhou esse movimento, deixando de ser o centro político, apenas reagindo às iniciativas de terceiros e não se adiantando a elas. Partido micheliano por excelência, na definição da autora, o diálogo entre diretórios regionais e a direção nacional não incluía admissão de dissidências. Esse foi o caso da disputa das "raposas" com o a "Ala Moça" no partido, com o esmagamento político do último grupo. A fragmentação interna do partido o conduziu para perigoso processo de desagregação (HIPPOLITO, 1985:137). Além disso, a vitória das "raposas" contribuiu para que partido não acompanhasse o movimento para a esquerda, deixando de ser o centro político do leque partidário. Segundo a autora, "quando o PSD se viu a reboque da conjuntura, reagindo a ela (e não mais se antecipando), o centro político do sistema desapareceu e o sistema partidário caminhou para o colapso" (HIPPOLITO, 1985:37).

Sobre o PTB, trabalho pioneiro é o de Lucilia de Almeida Neves Delgado, $P T B$, do getulismo ao reformismo, livro publicando em 1989, resultado de sua tese de doutoramento em Ciência Política na Universidade de São Paulo 
no mesmo ano. Trata-se de trabalho pioneiro sobre o Partido Trabalhista Brasileiro, centrando a discussão nas relações do partido entre a liderança de Getúlio Vargas, o movimento sindical e o Estado. ${ }^{8}$

Desde sua fundação e durante toda sua trajetória durante a experiência democrática, o PTB conviveu internamente com grandes disputas entre grupos e facções. Basicamente, a autora distingue a importância de dois deles: os chamados por Lucília Neves Delgado de "pragmáticos", com vocação para as práticas fisiológicas. Procurando na figura de Vargas o ícone para angariar votos e prestígio, os pragmáticos eram oriundos da burocracia do Estado Novo e tiveram papel importante na fundação do partido. O outro grupo é identificado pela autora como "doutrinários" ou "reformistas". Formado por vários nomes de relevo no partido, entre eles Alberto Pasqualini, Lúcio Bittencourt, Sérgio Magalhães, Leonel Brizola, Fernando Ferrari, entre outros, eles acreditavam que o partido teria que se organizar em torno de uma doutrina para dar mais consistência para o trabalhismo, libertando-se - ou pelo menos demonstrando mais independência - da liderança e do carisma pessoal de Vargas. Para a autora, as contradições e conflitos internos entre ideológicos reformistas e os políticos fisiológicos surgiram desde as origens do partido (DELGADO, 1989:52).

Desse modo, o livro de Lucília Neves Delgado aponta para o leitor os conflitos entre os grupos com a ascendência no partido dos reformistas na segunda metade dos anos 1950. Essa, aliás, é a tese central da autora: embora os conflitos e disputas entre os dois grupos tenham marcado a trajetória do partido até sua extinção em 1965, o PTB avançou de uma proposta inicial marcada pelo fisiologismo e personalismo para a defesa de projeto de maior consistência ideológica e de caráter fortemente reformista. Não casualmente o sub-título do livro: do getulismo ao reformismo.

Outra questão explorada no livro é a vinculação entre o partido, o movimento sindical e o Estado, criando-se uma relação de interdependência entre

$8 \mathrm{Na}$ primeira edição do livro, de 1989, a autora adota a terminologia "populismo" para definir o regime de 1946-1964. Tratava-se, sem dúvida, de um conceito amplamente utilizado na área de Ciências Humanas no Brasil na época. Na segunda edição do livro (São Paulo, LTr75, 2011), a autora, considerando o livro resultado de seu tempo, manteve o texto original. Contudo, incorporou novas pesquisas que se seguiram e superou a nomenclatura "populismo" para definir o período. 
eles. O partido, nesse sentido, atuou como canal de diálogo entre o movimento sindical e o Estado. O PTB, em sua avaliação, nasceu com uma dupla face e conviveu com essa ambigüidade intrínseca que o acompanhou por toda sua trajetória: "de um lado, suas raízes sugavam a seiva do paternalismo e do controle; de outro, pelo teor mobilizador e até reformista inerente ao seu programa, surgia como alternativa nova para a organização popular na qual não estaria inteiramente descartada uma vida potencialmente autonomista" (DELGADO, 1989:74).

O processo ocorreu no início dos anos 1950, com a ascensão de João Goulart na presidência do partido e, mais adiante, com sua nomeação para o Ministério do Trabalho. Tratou-se, para a autora, de um marco na história do partido. Para Lucilia Neves Delgado, o estilo Jango no Ministério, "acabaria por estimular e ampliar o prestígio do PTB e das lideranças sindicais junto ao governo. O alívio das pressões que até então existiam sobre os sindicatos, levou-os liderados por setores mais avançados da classe trabalhadora, a pisar, com firmeza, no terreno de uma mobilização fortemente reivindicativa. Com a predominância da linha da mobilização e concessão, iniciava-se uma nova fase para os sindicatos e para o PTB que se consolidaria ainda mais após a morte de Vargas" (DELGADO, 1989:151). Entre diversas alterações nas relações entre Estado-partido-movimento sindical, uma deve ser ressaltada: a aproximação, no plano sindical, entre o PTB e o PCB. A partir daí, trabalhistas e comunistas atuaram em alianças no movimento sindical.

Para Lucilia Neves, o PTB surgiu para atender os interesses políticos de Getúlio Vargas e como instrumento reivindicativo dos trabalhadores. Para a autora, "o anticomunismo foi elemento vital, apesar de não exclusivo, na fundação do PTB. A possibilidade de crescimento do PCB, a médio prazo, poderia ser forte obstáculo à execução dos planos continuistas de Vargas" (DELGADO, 1989:32). Na concepção da autora, portanto, o PTB surge como anteparo ao crescimento do PCB. Com o tempo, no entanto, o PTB criou fortes vínculos com os sindicatos, reforçando o controle estatal sobre o movimento sindical, mas também conhecendo uma forte guinada à esquerda.

Contudo, mesmo no período de maior avanço do projeto reformista no partido, durante o governo Goulart, o PTB não superou o fisiologismo e o clientelismo, marcas de seu nascimento. Trata-se da tese central da autora: o 
partido de dupla face, a dos pragmáticos e a dos reformistas. Segundo a autora, "a história do PTB foi a história de um paradoxo, de uma contradição adquirida, ao longo dos anos, traços de continuidade permeados por injunções e marcas de descontinuidades". Foi a história da construção de um projeto reformista, "e ao mesmo tempo da impossibilidade de construção do reformismo. Isso porque a marca do fisiologismo jamais se apagou do partido e a herança da manipulação varguista, mesmo tendo adquirido caráter secundário ao longo dos anos, não deixou jamais de ser uma tatuagem de marcas profundas na vida político-institucional do PTB" (DELGADO, 1989:292).

Também para o caso do PTB, importante é o livro Sindicatos, Carisma e Poder: o PTB de 1945-65, livro publicado em 1996 de Maria Celina D'Araújo, resultado de sua tese de doutorado em Ciência Política no IUPERJ em 1989.

Surgindo como um "partido para muitas missões", na definição da autora, o PTB surgiu sob a direção de cúpulas sindicais, mas também sob a orientação do projeto governista, particularmente do Departamento Nacional do Trabalho e sob o embalo do movimento queremista que promovia a participação dos trabalhadores no processo eleitoral em curso. Sindicalistas e ministerialistas, assim, foram os primeiros grupos formadores do PTB. Mas sobretudo o partido expressava o Brasil que se urbanizava e se industrializava rapidamente. O partido surgiu adotando práticas relacionais, sobretudo o clientelismo e a parentela - cujos nomes mais conhecidos eram os de Ivete Vargas e Lutero Vargas, mas também com bandeiras que defendiam o nacionalismo, a democracia, a defesa da cidadania social dos trabalhadores e a distribuição da renda - destacando-se os nomes de Sérgio Magalhães e Alberto Pasqualini na defesa de projeto doutrinário para o partido. Mas não se trata de interpretação similar a de Lucilia de Almeida Neves Delgado para quem o PTB foi marcado pela clivagem da ideologia versus pragmatismo. Para Maria Celina D'Araújo, “o nacionalismo do PTB não foi incompatível com o empreguismo, nem o reformismo foi antítese do clientelismo ou de atrelamento ao Estado. Ao contrário, foi bem-sucedido no partido e nas urnas quem conseguiu unir essas estratégias" (D’ARAUJO, 1996:170).

Na concepção da autora, o PTB teve origem carismática "extremamente marcado por personalismos e girou em torno da disputa do legado trabalhista de Vargas. O personalismo estava na sua origem e a competição entre 
lideranças secundárias pelo comando da agremiação” (D’ARAUJO, 1996:10). Desse modo, carisma e corporativismo, quadros ministerialistas com dirigentes sindicais, por meio de um partido, garantiram a liderança de Vargas nos embates eleitorais (D'ARAUJO, 1996:20). Maria Celina, nesse sentido, discorda das teses que definem o PTB como um partido criado por Vargas tão-somente para esvaziar a força do PCB entre os trabalhadores.

O PTB tinha uma característica que o diferenciava da UDN e do PSD: não era um partido federativo, mas altamente centralizado. Demonstrando força eleitoral na Guanabara e Rio Grande do Sul, os diretórios regionais (o de São Paulo em particular) eram obrigados a acatarem as decisões do Diretório Nacional. O partido, assim, conviveu com brigas internas, intervenções nos diretórios locais, facções conflitantes e lutas pelo poder. Via de regra, o resultado era a expulsão de dissidentes.

Definido por Maria Celina D'Araujo a partir das indicações teóricas de Robert Michels, o PTB também expressou a institucionalização do carisma de Vargas. Recorrendo a categorias weberianas, a autora caracteriza o PTB como partido de origem carismática, mas cuja liderança, Getulio Vargas, soube levar adiante o processo de rotinização do carisma, ao transferir para João Goulart a responsabilidade de gerir e falar pelo partido e pelo próprio trabalhismo. Marcado pelo personalismo de Vargas, diz a autora, "a dissidência não era tolerada, e sim encarada como uma ameaça à figura do fundador”. O PTB só obteve alguma estabilidade interna a partir do momento e que Goulart assumiu a chefia partidária, mas como o "escolhido", como o "ungido" (D'ARAUJO, 1996:61). O partido não se democratizou internamente, mas passou ao controle de Goulart que dominava o Diretório Nacional.

Sob a direção de Jango, o PTB aproximou-se ainda mais do movimento sindical. Para Maria Celina D’Araujo, o “PTB teve sem dúvida papel capital na transformação do sindicato em ator político visível e na definição de uma política que queria fazer do sindicato uma fonte de poder. (...) O partido se projetava de forma personalista, associando o chefe a grandes questões nacionais e fazendo das conquistas trabalhistas um subproduto da defesa da soberania nacional. Foi como partido de 'libertação nacional' que o PTB passou a interpelar o leitorado nos anos seguintes" (D’ARAUJO, 1996:96). Além da aproximação com os comunistas e o reforço dos laços com o movimento sindical, os 
trabalhistas, desde o contra-golpe liderado pelo general Henrique Lott buscou alianças nas facções nacionalistas e de esquerdas das Forças Armadas.

Ao chegar ao poder, em setembro de 1961, o PTB mostrava-se cada vez mais à esquerda. O próprio Leonel Brizola passou a disputar o poder no partido com Jango. A radicalização do processo político incitou esquerdas e direitas a procurarem os militares para dirimirem suas divergências. As alianças dos trabalhistas com os comunistas e com sargentos e marinheiros motivou ressentimentos nas Forças Armadas. Liderados pelos nacionalistas-reformistas, o PTB insistiu na estratégia parlamentar, mas optou, paralelamente, pela "estratégia da ação direta, mobilizando sindicatos, soldados, sargentos, e trabalhadores para fazerem pressão sobre o governo" (D’ARAUJO, 1996:145). Naquele momento, segundo a autora, o projeto reformista "era indissociável de uma tomada do poder estatal pelos setores mais radicais do partido" (D'ARAUJO, 1996:146).

Com essa reflexão, a autora chama a atenção para as responsabilidades do trabalhismo petebista na crise política que resultou no golpe de 1964. Para os militares, o PTB reunia postulados e personalidades que expressava o inimigo a ser combatido. "Ou seja, o golpe era contra o trabalhismo janguista e contra as alianças e compromissos que o PTB fazia com a esquerda civil e militar." Além disso, era o partido que estava no governo, o que mais se empenhou em fazer dos "trabalhadores um sustentáculo privilegiado do poder" e procurou tecer alianças com militares, contribuindo para divisões nas Forças Armadas. Por fim, porque o PTB "substimou a representação formal, lançando mão, com velocidade crescente, de vias de participação direta” (D'ARAUJO, 1996:140).9

9 Sobre o PTB e o trabalhismo poderiam ser explorados os seguintes trabalhos: BASTOS, Suely. A cisão do MTR com o PTB. In FLEISCHER, David (org.). Partidos políticos no Brasil. Brasília, Editora da UNB, 1981, vol. 1; BENEVIDES, Maria Victória. O PTB e o trabalbismo. Partido e sindicato em São Paulo (1945-1964). São Paulo, CEDEC/Brasiliense, 1989; BODEA, Miguel. Trabalbismo e populismo no Rio Grande do Sul. Porto Alegre, Editora da UFRGS, 1992; D囚ARAUJO, Maria Celina. \Partidos trabalhistas no Brasil: reflexões atuais $\bigotimes$. Estudos Históricos , volume 3 n. 6, 1990; FERREIRA, Jorge. O imaginário trabalhista. Getulismo, PTB e cultura política popular. Rio de Janeiro, Civilização Brasileira, 2005; GOMES, Angela de Castro. Partido Trabalhista Brasileiro (1945-1965): getulismo, trabalhismo, nacionalismo e reformas de base. In FERREIRA, Jorge e AARÃO REIS, Daniel (orgs.). Nacionalismo e reformismo radical (19451964). As esquerdas no Brasil, volume 2. Rio de Janeiro, Civilização Brasileira, 2007. 
Sobre o sistema partidário da época é obrigatório a referência ao trabalho de Antonio Lavareda, A democracia nas urnas. O processo partidário-eleitoral brasileiro (1945-1964), de 1999, trabalho resultado de tese de doutoramento em Ciência Política no IUPERJ, em 1990. Recorrendo a pluralidade e grande quantidade de fontes, o autor explora o sistema político-partidário, criticando três teses adotadas na literatura sobre o tema. A primeira afirma que o sistema partidária conhecia, ao final do período, processo de "desestruturação" ou "desinstitucionalização"; a segunda alude para o "formato" desse sistema que se encaminhava para a "bipolarização" ou para o crescimento de "partidos dominantes"; por fim, a terceira tese criticada defende o processo de "realinhamento partidário", com o declínio de partidos tradicionais, como o PSD e o PR e o crescimento do PTB e do PDC.

Utilizando vasto conjunto de dados para análise - tabelas, percentuais, gráficos e índices eleitorais, além de resultados de pesquisas do IBOPE, Lavareda descarta cada uma das teses. O sistema partidário não vivia processo de desagregação, nem de realinhamento com inversão das forças eleitorais. Seus argumentos são sólidos no sentido de recusar as interpretações que afirmam a "fragilidade" dos partidos políticos e, consequentemente, a pouca solidez do regime democrático no Brasil.

Para Antonio Lavareda, no início dos anos 1960, "o sistema partidário-eleitoral brasileiro às vésperas do seu fim qualifica-o como um sistema bastante completo em processo de consolidação". As pesquisas do IBOPE são reveladoras nesse sentido, particularmente quando revelam a identificação do eleitorado com os partidos políticos. Às vésperas do golpe militar, pesquisas do IBOPE apontavam para 64\% o índice de reconhecimento do eleitor com seu partido nas grandes capitais brasileiras.Tratava-se de um sistema partidário complexo que, embora com problemas inerentes às democracias representativas, conhecia crescente processo de institucionalização. Segundo o autor, "no início da década de 60, o sistema partidário-eleitoral experimentava, apesar dos obstáculos e embora de modo não uniforme, um processo de consolidação, que viria a ser frustrado pelo golpe militar" (LAVAREDA, 1999:134). Mesmo com as dificuldades existentes, o sistema partidário brasileiro entre 1945 e 1964 foi, para o autor, "uma experiência privilegiada”, combinando a ampliação dos direitos políticos dos cidadãos, a nacionalização dos partidos 
políticos e um rápido processo de urbanização que emancipou politicamente amplos contingentes da população (LAVAREDA, 1999:133-191).

Não se tratavam, portanto, de Partidos artificiais, em processo de desintegração, dominados por lideranças personalistas. Mais ainda, Lavareda demonstra que, ao final do período democrático, o eleitorado não endossava o processo de radicalização política promovido por determinadas lideranças partidárias. Com base nas pesquisas de opinião realizadas entre 1963 e 1964, Lavareda comprova "que a maioria do eleitorado se situava no centro do espectro político. Centro naturalmente ambíguo. Que não era imobilista, ao contrário, endossava várias das reformas preconizadas pelo presidente Goulart. (...) A radicalização era uma nítida opção estratégica de setores das elites, à esquerda e à direita, desinteressada na manutenção da institucionalidade democrática. O eleitor comum não tinha, rigorosamente, nenhuma responsabilidade nesse processo" (LAVAREDA, 1999:190). ${ }^{10}$

Ainda sobre a vida política na experiência democrática brasileira valeria aprofundar as teses de autores que se dedicaram ao estudo de governos do período. É o caso de Maria Victoria Benevides em seu livro que também se tornou clássico sobre o governo Juscelino Kubistchek (1979); Maria Celina D'Araújo sobre o segundo governo Vargas (1982); e o meu próprio trabalho sobre João Goulart (2011).

No conjunto, o que os autores citados nos apontam é que, pela primeira vez na história do país, surgiram e se fortaleceram partidos políticos nacionais com programas e perfis ideológicos definidos. Os estudos demonstram que, naquele período, se fortaleceu o vínculo programático e ideológico entre os partidos e o eleitorado. Não mais se tratavam dos partidos da época do Império ou das organizações estaduais da Primeira República, em ambos os casos instrumentos das elites. As diversas eleições - periódicas, ininterruptas e em todos os níveis - contribuíram para consolidar um sistema partidário nacional que expressava as diversas correntes de opinião do eleitorado.

\footnotetext{
10 Vale citar o importante trabalho de sociólogo Gláucio Ary Dillon Soares citado anteriormente, que realiza balanço exaustivo do regime de 1946 em diversas dimensões. Seus estudos e pesquisas o autorizam a caracterizar o período democrático "por uma extraordinária taxa de crescimento econômico, particularmente industrial, um claro e seguro progresso político, ainda que lento em certas áreas, e um desenvolvimento social muito lento" (2001:309).
} 


\section{O golpe civil-militar de 1964}

O golpe de Estado que, em 31 de março e $1^{\circ}$ de abril de 1964, derrubou o presidente João Goulart pode ser considerado como um dos temas mais estudados do período. Novamente sociólogos e cientistas políticos se destacam nos estudos sobre o assunto.

Octávio Ianni, em O colapso do populismo no Brasil, livro publicado em 1968, foi interpretação pioneira produzida na Universidade brasileira, sistematizando concepção que se tornou clássica. No livro, o determinismo econômico explica e fundamenta o golpe militar. ${ }^{11}$

O livro trata do "populismo", expressão que, na versão de seus formuladores, explicaria a política brasileira entre 1930, com a ascensão de Vargas ao poder, e 1964, quando teria ocorrido o seu "colapso". Junto com Francisco Weffort, Octávio Ianni tornou-se nome clássico na invenção da expressão “populismo”. Para Ianni, “inicialmente, esse populismo é exclusivamente getulista. Depois, adquire outras conotações e, também, denominações" (IANNI, 1968:206). Assim, importantes tradições políticas da época, como trabalhistas, pessedistas, udenistas, comunistas, entre outros projetos institucionalizados em partidos políticos, foram renomeados de "populistas".

Ianni, ao longo do livro desenvolve o que define com "modelo getuliano de desenvolvimento econômico". Ele seria constituído pelo processo de industrialização por substituição de importações, dirigismo estatal, política externa independente, acomodação de interesses do proletariado, das classes médias e da burguesia industrial e a "política de massas" - estratégia perversa do líder carismático para manipular o povo. O peleguismo, outro elemento importante do "populismo", controlaria o movimento

11 Outros estudiosos também recorreram ao determinismo econômico para explicar o golpe militar de 1964. Guilherme O’Donnel vinculou o regime militar ao processo de industrialização por substituição de importações: em um certo estágio, o crescimento econômico exige governos autocráticos na regulação dos conflitos. Para Fernando Henrique Cardoso, em visão ainda mais determinista, a acumulação de capital necessita de formas autoritárias para desarmar o movimento sindical e reestruturar os mecanismos de acumulação de capital. Ver O'DONNELL, Guilherme. Modernização y autoritarismo. Buenos Aires, Paidós, 1972 e CARDOSO, Fernando Henrique."Associated-Dependent Develpmente: Theoretical and Practical Implications". In STEPAN, Alfred (ed.). Authoritarian Brazil. New Haven, Yale University Press, 1973. 
sindical. Recorrendo à teoria da modernização, em particular Gino Germani e Torquato di Tella, Octávio Ianni interpreta o "populismo" e o "modelo getuliano de desenvolvimento econômico" como a passagem da sociedade rural para a urbana com a chegada, nas cidades, de levas camponesas imbuídas de valores tradicionais do mundo rural. Como os trabalhadores não se organizavam como classe, eles se apresentam como massas - matéria-prima de que serviam os líderes "populistas". As esquerdas, o PCB em particular, vergaram-se à política populista, prejudicando o processo de tomada de consciência de classe dos trabalhadores. Seja como for, Ianni vê avanços em termos econômicos e sociais no "populismo". Os dados que cita mostram o crescimento econômico e os benefícios gerados pela legislação social.

Houve, porém, um movimento contraditório no período "populista". Durante o governo de Juscelino Kubitschek, a política de massas teve continuidade, mas, com a entrada das empresas multinacionais no país, os compromissos com os capitais externos foram crescentes. Assim, o modelo de desenvolvimento patrocinado por JK, com a interdependência com os capitais estrangeiros, criou as condições para a liquidação do desenvolvimento nacionalista.

Desse modo, no embate entre dois projetos de desenvolvimento - o nacionalista e o associado com o capital estrangeiro, o "modelo getuliano de desenvolvimento econômico" encontrou no governo Goulart os seus limites. "A democracia populista", afirma o autor, "tinha diante de si uma única opção: continuar a revolução brasileira, realizar nova etapa do modelo getuliano". No embate com o modelo associativo, o nacionalismo getuliano poderia avançar no que havia de positivo, como a industrialização, a política externa independente, o florescimento cultural, entre outros elementos.

O modelo getuliano somente poderia ser negado "sob duas formas radicais: a revolução socialista ou a reintegração plena no capitalismo mundial” (IANNI, 1968:122). Assim, durante o governo Goulart, "o povo brasileiro defronta-se de modo cada vez mais premente com a necessidade de adotar uma opção drástica”. Para Ianni, o conflito foi resolvido com a deposição de João Goulart da presidência da República: "O Golpe de Estado de $1^{\circ}$ de abril de 1964 assinala a transição efetiva para o modelo de desenvolvimento econômico associado. Implica na combinação e reagrupamento de empresas brasileiras e estrangeiras, 
com a formação de uma nova concepção de interdependência econômica, política, cultural e militar, na América Latina e com os Estados Unidos” (IANNI, 1968:11). Avançando em sua interpretação baseada no determinismo econômico, Ianni afirma que "em verdade, o golpe de $1^{\circ}$ de abril de 1964 é o fecho do longo processo de transição no Brasil da esfera da libra esterlina para a esfera do dólar" (IANNI, 1968:145). Com o golpe militar, a "democracia populista" foi substituída pela "ditadura da burguesia" (IANNI, 1968:211).

O livro de Octávio Ianni tornou-se bastante divulgado, sendo reeditado durante muitos anos. Trata-se, no entanto, de livro datado historicamente, escrito sob determinada conjuntura política. Terminado de ser redigido em fins de 1967, o livro foi publicado no ano seguinte, antes da edição do Ato Institucional n. 5 que instituiu, de maneira aberta, a ditadura no Brasil. Trata-se de momento de crescente radicalização política, tanto dos militares conhecidos como "linha dura" quanto dos jovens que, professando o marxismo-leninismo, entusiasmavam-se em pegar em armar para atacar a ditadura. $\mathrm{O}$ livro foi redigido nesse contexto de radicalização. A frase final do livro é esclarecedora nesse sentido: "O populismo terá sido apenas uma etapa na história das relações entre as classes sociais. Nesse sentido é que se pode dizer que no limite do populismo está a luta de classes. Da mesma forma, no limite da ditadura de vocação fascista pode estar a sociedade socialista" (IANNI, 1968:213). Fascismo ou socialista, eis as opções para a sociedade brasileira na interpretação Ianni. Com variações, eram as visões de futuro das esquerdas que se preparavam para tomar em armas.

Em 1977, treze anos após o golpe militar, o cientista político Moniz Bandeira escreveu o primeiro livro sobre a história do governo Goulart e do próprio golpe militar. Superando as versões economicistas e os ensaios sociológicos, Bandeira recorreu ao método histórico e publicou $O$ governo João Goulart, as lutas sociais no Brasil, 1961-1964. O livro teve seguidas reimpressões, algumas delas revistas e ampliadas. A oitava edição é de 2010. Com base em farta documentação, tanto do governo norte-americano quanto do próprio arquivo pessoal de João Goulart, Bandeira, em minha compreensão, escreveu livro pioneiro e obrigatório para o tema.

Moniz Bandeira identifica, naquela temporalidade, lutas sociais acirradas em torno das reformas de base. Em uma dimensão, o país conheceu conflitos 
entre direitas e esquerdas a favor ou contra as reformas; em outra, tensões entre os governos brasileiros e o norte-americano. Além disso, o contexto internacional marcado pelos conflitos ideológicos da Guerra Fria, em particular o caso cubano, também foi determinante para na crescente deterioração do governo.

Muito resumidamente, o livro de Bandeira tem por base dois pilares interpretativos. O primeiro deles, a perspectiva positiva sobre João Goulart, seu governo e o Partido Trabalhista Brasileiro. Segundo sua interpretação, Goulart "não atuava como um demagogo, que entorpecia as massas e as desorganizava, para resguardar o domínio do grande capital, a exemplo do que Jânio Quadros e Ademar de Barros faziam. De acordo com a tipologia de Darcy Ribeiro, era um reformista. E sua política se assentou fundamentalmente na massa organizada, nos sindicatos e num partido político, o PTB, bem ou mal um partido de composição operária" (BANDEIRA, 1977:28) O segundo pilar interpretativo é a ação desestabilizadora exercida pelo governo dos Estados Unidos contra o governo Goulart. A CIA e as empresas multinacionais, nesse sentido, atuaram de maneira acintosa no financiamento de organizações empresariais de oposição ao governo, como o IPES, o IBAD e diversas outras. Nas palavras do autor, "com esse primoroso trabalho de corrupção, inédito na história do País, a CIA não somente aliciou empresários, vereadores, deputados estaduais e federais, senadores, governadores de estado, jornalistas, donas-de-casa, estudantes, dirigentes sindicais, padres e camponeses, enfim, a choldra de todas as classes e categorias da sociedade civil brasileira" (BANDEIRA, 1977:70). Incluindo, também, os militares. Na revolta dos marinheiros Moniz Bandeira identifica a participação da CIA na preparação do motim (BANDEIRA, 1977:169).

Embora considere em suas análises a processo de radicalização das direitas e das esquerdas e a atuação de Goulart de buscar o consenso como elementos explicativos para a crise do regime democrático no Brasil, Moniz Bandeira centra o foco de sua análise no papel desestabilizador do governo dos Estados Unidos que, por meio da CIA, atuou no sentido de minar as bases políticas e sociais do governo, resultando no golpe militar.

A análise de Moniz Bandeira parte dos pressupostos dos próprios trabalhistas: o golpe foi resultado de conspiração interna de políticos e empresários 
conservadores com apoio externo do governo dos Estados Unidos. A conspiração interna-externa visava impedir a efetivação das reformas econômicas e sociais e a ascensão política dos trabalhadores.

Wanderley Guilherme dos Santos inovou ao incluir variáveis políticas para a compreensão do golpe militar, relativizando o determinismo econômico e a conspiração norte-americana. Sessenta e quatro: anatomia de uma crise é resultado de seu doutoramento em Ciência Política na Stanford University em 1979, mas publicado em livro ao público brasileiro em 1986. A crise de março de 1964 não decorreu de alterações econômicas resultantes do processo de modernização ocorrido nos anos 1950 ou de problemas decorrentes da incapacidade dos partidos políticos de manterem suas alianças visando apoiar as iniciativas governamentais. Wanderley Guilherme dos Santos não compactua com versões deterministas. Para ele, o regime da Carta de 1945 não estava condenado ao colapso.

Para o autor, na virada dos anos 1950 para os 1960 houve um acirramento ideológico, resultando na transformação de um sistema pluralista moderado para um pluralismo extremamente polarizado. E sistemas polarizados resultam, via de regra, em "paralisia decisória”. Foi o que ocorreu no governo Goulart. O golpe militar, nesse sentido, não resultou da reação de grupos insatisfeitos com as medidas tomadas pelo governo. A radicalização política, para ele, foi o elemento central que impediu a implementação de compromissos e cooperação entre os partidos políticos. Segundo o autor, "a radicalização de um lado, como tática para testar as boas intenções do outro, resultou apenas num aumento das suspeitas de ambos os lados. O resultado final foi uma diminuição da capacidade de negociação e de transigência” (SANTOS, 1986:25).

Assim, no âmbito do legislativo inexistiram coalizões estáveis. Os parlamentares não tinham compromissos com reformas econômicas e sociais negociadas politicamente, preferindo a agitação política e ideológica. Goulart, por seu turno, realizou diversas reformas ministeriais com o objetivo de angariar prestígio junto aos partidos políticos e encontrar apoio às reformas de base. Entre a rotatividade dos cargos, o tênue apoio dos partidos políticos ao governo e o receio de Jango tornar-se refém dos grupos conservadores no Congresso Nacional, houve um agravante: o medo dos parlamentares 
de direita das reais intenções de Goulart. O presidente acreditava que o Congresso Nacional era mesmo conservador e não aprovaria a reforma agrária; a direita parlamentar desconfiava do presidente, sobretudo de alterações nas regras eleitorais. Segundo avaliação do autor, "a crise brasileira de 1964 foi uma crise de paralisia decisória, ou seja, um colapso do sistema político, resultante de sua incapacidade de funcionar (isto é, de tomar decisões sobre questões conflitantes) e não a conseqüência de algum programa governamental específico, consistentemente implementado" (SANTOS, 1986:10).

Resumindo, o colapso da democracia em 1964 resultou daquilo que o autor definiu como "paralisia de decisão", processo composto de quatro combinações: fragmentação de recursos de poder, radicalização ideológica, fluidez nas coalizões partidárias no Congresso Nacional e rotatividade nos ministérios resultando na instabilidade do próprio governo.

Contudo, Wanderley Guilherme dos Santos insiste que o regime não estava condenado. Havia um centro político importante disposto a negociações para apoiar as reformas de base. O processo de radicalização política, no entanto, impediu soluções negociadas politicamente para a crise.

Atualmente, duas grandes referências, ambas produzidas na área da Ciência Política, apontam para linhas de reflexões sobre golpe de 1964.

A primeira é a de René Dreifuss, 1964: a conquista do Estado. Ação politica, poder e golpe de classe, publicado em 1981 e resultado de seu doutoramento em Ciência Política na Universidade de Glasgow no ano anterior. Para o autor, o Instituto de Pesquisas e Estudos Sociais (IPES) e o Instituto Brasileiro de Ação Democrática (IBAD), durante o governo Goulart, agiram como uma espécie de "Estado-Maior da burguesia multinacional-associada". Utilizando categorias marxistas e grasmcianas, Dreyfuss identifica uma "elite orgânica" formada por empresários, militares e intelectuais que, representando interesses financeiros multinacionais, exerciam ações no sentido de desestabilizar o governo Goulart. O que até então autores atribuíam às Forças Armadas, no trabalho de Dreifuss passa à responsabilidade do "complexo IPES-IBADE" que, em março de 1964, teria perpetrado um "golpe de classe".

As duas organizações, agindo em conjunto, são interpretadas como o "partido da burguesia". Formaram o Estado-Maior da burguesia nacional associada ao capital estrangeiro com o objetivo de agir em termos ideológicos, políticos 
e militares. O processo tem origem no peso que as empresas multinacionais adquiriram em fins dos anos 1950 no Brasil. O capital transnacional apresentava poderio econômico, mas também perícia organizacional e capacidade política "para influenciar as diretrizes políticas no Brasil. Essa perícia e capacidade foram incorporadas em uma intelligentsia política, militar, técnica e empresarial, isto é, nos intelectuais orgânicos dos interesses multinacionais e associados e nos organizadores do capitalismo brasileiro" (DREIFUSS, 1981:66). Caberia aos intelectuais orgânicos do bloco oligopolista assumir a liderança do país, desalojando do poder os grupos políticos tradicionais identificados com o projeto "populista".

Do domínio econômico em fins dos anos 1950, o capital multinacional e associados nacionais criaram e atuaram em agências para desenvolver a ação e o golpe de classe - o IPES e o IBAD. Os objetivos, quando alcançassem o poder político, seriam, de imediato, reprimir as esquerdas e restringir a participação e as liberdades do movimento sindical. Ao mesmo tempo, o novo "bloco no poder" teria como tarefa promover o desenvolvimento econômico, embora dependente dos grandes centros capitalistas, concentrando e integrando capitais bancários, além de apoiar os interesses econômicos das empresas multinacionais. A garantia política para a imposição desse projeto de classe seria oferecida pelas Forças Armadas.

Utilizando de vasta campanha publicitária, o "complexo IPES-IBAD" elaborou e difundiu campanha anticomunista, convencendo a sociedade de que Goulart tinha o objetivo de comunizar o Brasil. Segundo o autor, "o complexo IPES-IBAD estava engajado em uma vasta campanha que procurava manipular a opinião pública e doutrinar as forças sociais empresariais, modelando esses interesses em uma classe 'para si'. Além disso, ele estava envolvido em uma abrangente campanha que visava impedir a solidariedade das classes trabalhadoras, conter a sindicalização e mobilização dos camponeses, apoiar as clivagens ideológicas de direita na estrutura eclesiástica, desagregar o movimento estudantil e bloquear as forças nacional-reformistas no Congresso e, ao mesmo tempo, mobilizar as classes médias como 'massa de manobra' da própria elite orgânica" (DREIFUSS, 1981:281).

A campanha ideológica desestabilizou o governo e, com apoio dos militares, um novo grupo dominante formado por empresários da indústria e das 
finanças multinacionais associado a empresários brasileiros tomou o poder em março de 1964. A derrocada da democracia no Brasil, por essa interpretação, é compreendida como inevitável.

A segunda importante referência é o trabalho de Argelina Figueiredo em Democracia ou reformas? Alternativas democráticas à crise política: 19611964, livro publicado em 1993 e resultado de tese de doutoramento em Ciência Política na University of Chicago em 1987. Recusando as interpretações estruturais - seja o determinismo econômico ou político - ou as intencionais - como a da "incompetência" pessoal de Goulart ou a ação de "elites orgânicas" que conspiraram contra o regime -, a autora concentra-e na conduta estratégica de atores políticos em situações históricas determinadas. Desse modo, "as escolhas deliberadas e intencionais feitas pelos atores são o ponto de partida para a análise" (FIGUEIREDO, 1993:29). Para Argelina Figueiredo, entre 1961 e 1964, "escolhas e ações específicas solaparam as possibilidades de ampliação e consolidação de apoio para as reformas, e, desta forma, reduziram as oportunidades de implementar, sob regras democráticas, um compromisso sobre estas reformas" (FIGUEIREDO, 1993:30).

Dois momentos durante o governo Goulart foram decisivos para a resolução do conflito político e a implementação de reformas econômicas e sociais moderadas dentro da ordem democrática. O primeiro deles foi a experiência parlamentarista. Para a autora, a manutenção do parlamentarismo e sua institucionalização poderiam resultar em reformas moderadas e negociadas no Congresso Nacional. Contudo, Goulart, as esquerdas, influentes setores militares e os próprios presidenciáveis - como Juscelino Kubistchek, Magalhães Pinto e Carlos Lacerda - conspiraram pelo fracasso do regime. O segundo momento foi o Plano Trienal, interpretado pela autora como uma proposta de pacto social. Com o plano de estabilização econômica, empresários e trabalhadores perderiam momentaneamente, mas ganhariam mais adiante com o controle do processo inflacionário. No entanto, esquerdas, movimento sindical e o empresariado mostraram renitente oposição ao plano de estabilização. A incapacidade de negociação entre esquerdas e conservadores se manifestou em diversos episódios, sendo um dos mais importantes a proposta de reforma agrária governamental enviada ao Congresso Nacional. Aceita por setores do empresariado, bem como de importantes grupos dentro do PSD e da UDN, o 
projeto enviado por Goulart foi interpretado como moderado em demasia pelas esquerdas, sendo combatida pelo próprio partido governista, o PTB, que exigia o programa máximo de reformas.

Os seguidos fracassos tornaram inviáveis a possibilidade de formação de uma frente de centro-esquerda que garantisse as reformas e detivesse o crescimento das direitas. Escolhas e decisões tomadas pelos atores envolvidos naquele processo estreitaram as opções políticas disponíveis, reduzindo cada vez mais as oportunidades de realizar as reformas - mesmo que moderadas dentro das regras democráticas.

A crescente radicalização das direitas e das esquerdas produziu o consenso negativo sobre as possibilidades de resolverem as diferenças e os conflitos sob regime democrático, resultando na desestabilização do governo. Direitas e esquerdas tinham percepção instrumental do significado de democracia. Para garantir seus privilégios, as direitas estiveram dispostas a romper com as regras democráticas. Se não fossem garantidos, era preferível sacrificar a democracia. As esquerdas, por sua vez, lutavam pelas reformas a qualquer preço e custo, inclusive com o sacrifício das instituições liberaldemocráticas da Constituição de 1946. Direitas e esquerdas, diz a autora, "subscreviam a noção de governo democrático apenas no que servisse às suas conveniências. Nenhum deles aceitava a incerteza inerente às regras democráticas»(FIGUEIREDO, 1993:202). Ao final, o regime da Carta de 1946 não resistiu aos confrontos, resultando no pior dos mundos: nem democracia, nem reformas.

Embora com suas diferenças, o resultado das pesquisas de vários historiadores aproximam-se das teses de Wanderley Guilherme dos Santos e Argelina Figueiredo. A começar por Maria Celina D'Araújo e sua interpretação do papel do PTB na crise de 1964. Antonio Lavareda, em seu trabalho também citado anteriormente e fundamentado em sólida pesquisa, demonstra que em meio à crescente radicalização das esquerdas e das direitas, "a opinião pública brasileira estava ancorada, em sua maioria, ao centro", mas que apoiava as reformas defendidas por João Goulart. "O governo gozava de simpatia e razoável credibilidade", afirma Lavareda. "A radicalização que terminaria por destruir a ordem constitucional, era apenas uma opção estratégica das elites desinteressadas no jogo democrático" (LAVAREDA, 1999:180 e 1-2). 
Rodrigo Patto Sá Motta avalia de maneira crítica as interpretações que ressaltam a propaganda anticomunista para a crise do governo Goulart e sua posterior deposição. Com base em ampla pesquisa sobre o anticomunismo no Brasil, Rodrigo Motta afirma que "há algum exagero na suposição de que o temor ao comunismo fosse meramente uma manobra utilizada por conspiradores ocultos, viando a conduzir uma massa de tolos em direção ao golpe" (MOTTA, 2006:143). Foi a aproximação de Goulart das esquerdas que assustou as elites conservadoras e permitiu que o discurso anticomunista reverberasse na sociedade brasileira. Para Motta, "foi somente no início de 1964 que a coalizão conservadora majoritariamente se inclinou pela ruptura institucional. Até então, a direita radical estava isolada em relação à opinião conservadora”. Daniel Aarão Reis também é crítico das teses que apontam a propaganda anticomunista como o fator determinante para o golpe de 1964, dando ao IPES e ao IBAD, por exemplo, o domínio sobre o rumo dos acontecimentos. Para o autor, "seria simplório imaginar que tudo se limitou a manobras de manipulação”, como se os receptores das mensagens anticomunistas recebessem de maneira passiva a propaganda ideológica (AARÃO REIS, 2001:335). Na biografia que escrevi sobre João Goulart, demonstro a polarização ideológica entre direitas e esquerdas que, em processo crescente de radicalização, resultou na desestabilização do governo Goulart e sua derrubada por um golpe de Estado (FERREIRA, 2011).

Gláucio Ary Dillon Soares, com base em pesquisa coletiva sobre militares no Brasil, é crítico contundente das teses conspiratórias: "O economicismo do pensamento político e social na América Latina fez com que se fosse buscar nas elites econômicas os responsáveis pelo golpe. O golpe, porém, foi essencialmente militar: não foi dado pela burguesia nem pela classe média, independentemente do apoio que estas lhes prestaram. Na medida que o golpe foi dado pelos militares e o regime daí resultante foi dirigido pelas Forças Armadas e exercido em nome delas, as interpretações anteriores ao fim do regime, sem acesso às fontes militares, insistiram na interpretação economicista, mas adotando uma segunda linha de defesa, segundo a qual o golpe teria sido dado pelos militares em nome das elites econômicas. Esse é um dos erros mais crassos do marxismo vulgar: supor 
que há grupos ou instituições que não agem em defesa de seus próprios interesses, e sim dos interesses de outra classe ou de outros grupos a que estariam subordinados”. Para o autor, as Forças Armadas, em 1964, não estiveram a soldo dos interesses da burguesia, das classes médias ou de qualquer outro setor social, mas levaram em consideração seus próprios interesses, como qualquer outra instituição ou grupo e classe social (SOARES, 2001, 351).

Muitos historiadores marxistas brasileiros consideram as teses que ressaltam a conspiração de grupos empresariais e/ou a participação norteamericana como fator explicativo central para o golpe de 1964. Contudo, mesmo nos meios historiográficos marxistas, há vozes dissonantes. É o caso de Jacob Gorender, nome expoente no pensamento marxista brasileiro. Segundo sua interpretação, o "golpe de 64, até talvez dezembro de 1963 ou janeiro de 1964, ainda não era inevitável”. Além disso "é uma idéia falsa a de que os golpistas estivessem fortemente articulados" e "não corresponde à realidade a idéia de que os conspiradores golpistas possuíam planos perfeitamente elaborados para tudo", afirma Gorender. Em sua interpretação, a partir de novembro de 1963 Goulart aliou-se às esquerdas, o PCB em particular, "germinando uma idéia golpista. Esta inspiração golpista está visível nos documentos que temos à disposição. (...) Havia, pois, golpismo, não só da direita, mas também da esquerda”. Portanto, avalia Gorender, "o golpe não era inevitável. Contudo, tornou-se inevitável na curta conjuntura dos dois ou três meses que o antecederam" (GORENDER, 1997:109-110 e 114).

O golpe civil-militar de 1964 foi acontecimento marcante do século XX brasileiro. É marco na história política do país e de toda uma geração de brasileiros. Ao lado das pesquisas que apontam para o processo de radicalização entre esquerdas e direitas que desestabilizaram o governo coexistem as teses que afirmam a conspiração anticomunista como elemento determinante para o golpe. A continuidade das pesquisas sobre a crise política do governo Goulart e o golpe de 1964, portanto, é necessária para o avanço do conhecimento sobre o tema. 


\section{Finalizando: de um século a outro}

A partir da década de 1980, muitas pesquisas têm sido produzidas nos programas de pós-graduação em História nas Universidades brasileiras. Foi nessa década que ocorreu o processo de expansão dos cursos de mestrado e doutorado. Mas também nessa década os historiadores brasileiros vivenciaram forte inflexão no seu campo de atuação com a crise dos modelos interpretativos. Ocorreu, naqueles anos, vigorosa revisão historiográfica. Modelos teóricos globalizantes que induziam o pesquisador a análises baseadas em linearidades ou previsibilidades foram abandonados (GOMES, 2004:160). A História Política e a História Cultural contribuíram para enfoques inovadores, ao mesmo tempo que atuaram no sentido de convidar os historiadores a abandonarem explicações fundamentadas em variáveis exteriores aos próprios personagens históricos.

Muitos historiadores, em suas pesquisas de mestrado e doutorado, contribuíram para a renovação dos estudos sobre a experiência democrática brasileira com trabalhos originais, exaustivo levantamento de fontes e com abordagens inovadoras. Desde a década de 1980, jovens pesquisadores souberam trabalhar no cruzamento da História de Gênero com a História Política, ${ }^{12}$ enquanto outros dedicaram-se ao estudo da produção artística ${ }^{13}$ e da atuação

12 CORDEIRO, Janaína Martins. "A Nação que se salvou a si mesma". Entre Memória e História, a Campanha da Mulber pela Democracia (1962-1974). Dissertação de mestrado. Niterói, Universidade Federal Fluminense, 2008; MACEDO, Elza Dely Veloso. Ordem na casa e vamos à luta! Movimento de mulheres: Rio de Janeiro 1945-1964. Lydia da Cunha - uma militante. Tese de doutorado. Niteroi, Universidade Federal Fluminense, 2001; SESTINI, Dhärana Pérola Ricardo. $A$ "mulher brasileira" em ação: motivações e imperativos para o golpe de 1964. Dissertação de mestrado. São Paulo, Universidade de São Paulo, 2008.

13 POLlETO, Fábio Guilherme. Tom Jobim e a modernidade musical brasileira (1953-1958). Dissertação de mestrado. Curitiba, Universidade Federal do Paraná, 2004; VIDAL, Erick de Oliveira. As capas da Bossa: encontros e desencontros dessa história visual (LPs da Elenco, 1963). Dissertação de mestrado. Juiz de Fora, Universidade Federal de Juiz de Fora, 2008; ZACHILINSKI, Beatriz Polidori. Imagens do casamento e do amor em Nelson Rodrigues: um estudo das representações de gênero na ficção publicada em jornal entre 1944 e 1961. Dissertação de mestrado. Curitiba, Universidade Federal do Paraná, 2006. 
dos meios de comunicação. ${ }^{14}$ Os temas tradicionais também foram revisitados de maneira inovadora pela nova geração de historiadores, como a História Militar, ${ }^{15}$ História do Trabalho, ${ }^{16}$ os partidos políticos ${ }^{17}$ e a política externa. ${ }^{18}$

14 AZEVEDO, Lia Calabre. No tempo do rádio: radiodifusão e cotidiano no Brasil: 19231960. Tese de doutorado). Niteroi, UFF, 2002; VALIM, Alexandre Busko. Imagens vigiadas: uma bistória social do cinema no alvorecer da Guerra Fria, 1945-1954. Tese de doutorado. Niterói, Universidade Federal Fluminense, 2006; SILVA, Herber Ricardo da. A democracia impressa: transição do campo jornalístico e do político e a cassação do PCB nas páginas da grande imprensa, 1945-1948. Dissertação de mestrado). Assis, UNESP, 2008.

15 ALMEIDA, Anderson da Silva. Todo o leme a bombordo. Marinheiros e ditadura civilmilitar no Brasil: da rebelião de 1964 à anistia. Dissertação (Mestrado). Niteroi, 2010; CARLONI, Karla Guilherme. Marechal Henrique Teixeira Lott: a opção das esquerdas. Tese (Doutorado). Niteroi, UFF, 2010; LOPES, Fabiana Luis Bueno. Batalhão Suez: história, memória e representação coletiva (1956-2000). Dissertação (Mestrado). Curitiba, Universidade Federal do Paraná, 2006.

16 Ver BATAlHA, Cláudio Henrique de Moraes; SILVA, Fernando Teixeira da; FORTES, Alexandre (orgs.) . Culturas de classe. Identidade e diversidade na formação do operariado.. 1. ed. Campinas, Editora da Unicamp, 2004; COSTA, Hélio da. Em busca da memória. Comissão de fábrica, partido e sindicato no pós-guerra. São Paulo, Scritta, 1995; SILVA, Fernando Teixeira da. A carga e a culpa. Os operários das docas de Santos: direitos e cultura de solidariedade. 1937-1968. São Paulo/Santos. Hucitec/Prefeitura Municipal de Santos, 1995; FONTES, Paulo. Trabalhadores e cidadãos. Nitro Química: a fábrica e as lutas operárias nos anos 50. São Paulo, Annablume/Sindicato Químicos e plásticos-SP, 1997; NEGRO, A. L. Linhas de Montagem. O Industrialismo Nacional-Desenvolvimentista e a Sindicalização dos Trabalhadores. São Paulo: Boitempo, 2004; NEGRO, Antonio L.; SILVA, Fernando T.; COSTA, Hélio da; FONTES, Paulo; FORTES, Alexandre. Na luta por direitos. Estudos recentes em História Social do Trabalho. Campinas, Ed. da Unicamp, 1999; SANTANA, Marco Aurélio. Homens partidos. Comunistas e sindicatos no Brasil. São Paulo/Rio de Janeiro, Editorial Boitempo/Universidade do Rio de Janeiro, 2001.

17 CRUZ, João Batista Carvalho da. Da formação ao desafio das urnas: o PTB e seus adversários nas eleições estaduais de 1947 no Rio Grande do Sul. Dissertação (Mestrado). São Leopoldo, Universidade do Vale do Rio dos Sinos, 2010; JANES, Andréia Rezende Perez. O PTB: entre o Estado e as massas (1960-1964). Dissertação (Mestrado). Vitória, Universidade Federal do Espírito Santo, 2007; LIMA, Jailma Maria de. Partidos, candidatos e eleitores. O Rio Grande do Norte em campanha política (1945-1955). Tese (Doutorado). Niteroi, Universidade Federal Fluminense, 2010; OLIVEIRA, Lisandre Madianeira de. O PSD no Rio Grande do Sul: o diretório mais dissidente do país nas "páginas" do Diário de Notícias. Tese (Doutorado). Porto Alegre, PUC-RS, 2008; TAUFER, Paulo Roberto. Partido Libertador: formação e atuação politica. Dissertação (Mestrado). São Leopoldo, Universidade do Vale do Rio dos Sinos, 2008.

18 COSTA, Marcelo Fernando Gonzalez da. As repercussões da política externa argentina no primeiro governo Perón (1946-1952) na imprensa sul-riograndense. Dissertação (Mestrado). São Leopoldo, Universidade do Vale do Rio dos Sinos, 2004; ELEK, Patrícia Braga. A Operação Pan-Americana: Uma discussão da relação entre política interna e política externa no governo 
A História Política tomou a atenção de muito deles, ${ }^{19}$ inclusive os que tratam da educação popular e da História da Ciência. ${ }^{20}$

Apesar das mudanças na prática historiográfica e o incentivo à pesquisa desde os anos 1980, o período 1946-1964 continua a merecer maior dedicação dos historiadores. Afinal, trata-se da primeira experiência democrática vivida pela sociedade brasileira.

Juscelino Kubitschek. Dissertação (Mestrado). Rio de Janeiro, UERJ, 2009; GONZAGA, André Luís. A política externa brasileira e a questão palestina: análise da imprensa e da diplomacia no período de 1945-1951. Dissertação (Mestrado). Assis, UNESP, 2008.

19 BRETAS, Manuela. Violão de Rua: memória, discurso e identidade da poesia revolucionária dos anos 60 (1962-1963). Dissertação de mestrado. Rio de Janeiro, Programa de PósGraduação em Memória Social da Uni-Rio, 2007; FOGAGNOLI, Marcela Martins. Almoçar bem é no SAPS!: os trabalhadores e o Serviço de Alimentação da Previdência Social (1940-1950). Dissertação (Mestrado). Niteroi, Universidade Federal Fluminense, 2011; MARTINS, Marisângela Terezinha Antunes. De volta para o presente: Uma história dos militantes comunistas de Porto Alegre e suas representações acerca da democracia (1945-1947). Dissertação (Mestrado). Porto Alegre, Universidade Federal do Rio Grande do Sul, 2007; OLIVEIRA, José Alberto Saldanha. $O$ mito do poder jovem: a construção da identidade da UNE. Tese de doutorado. Niteroi, Universidade Federal Fluminense, 2001; QUELLER, José. Entre o mito e a propaganda política: Jânio Quadros e sua imagem pública (1959-1961). Tese de doutorado. Campinas, UNICAMP, 2008; RIBEIRO, Jayme Lúcio. Os "combatentes da paz": a participação dos comunistas brasileiros na Campanha Pela Proibição das Armas Atômicas (1950). Dissertação de mestrado. Niteroi, Universidade Federal Fluminense, 2003; SANTOS, Soanne Cristino Almeida. Nacionalismo de esquerda: Frente de Mobilização Popular em Una (1963-1964). Dissertação de mestrado. Santo Antônio de Jesus, UNEB, 2010; SILVA, Tatyanne de Azevedo e. Sob a lógica da desconfiança: a polícia política e a campanha O Petróleo é Nosso! (1947-1953). Dissertação de mestrado. Niteroi, História da Universidade Federal Fluminense, 2006.

20 ROLIM, Tácito Thadeu Leite. Giram os Sputniks nas alturas, ferve a imaginação nas planuras: a ciência e o bizarro no Ceará em fins da década de 1950. Dissertação de mestrado. Fortaleza, Universidade Federal do Ceará, 2006; SOUZA, Claudia Moraes de. Pelas ondas do rádio: cultura popular, camponeses e o MEB. Dissertação de mestrado. São Paulo, Universidade de São Paulo, 2007; TEIXEIRA, Wagner da Silva. Educação em tempos de luta. História dos movimentos de educação e cultura popular (1958-1964). Tese de doutorado. Niteroi, Universidade Federal Fluminense, 2008. 


\section{Bibliografia}

AARÃO REIS, Daniel. O colapso do colapso do populismo ou a propósito de uma herança maldita. In FERREIRA, Jorge (org.). O populismo e sua história. Debate e crítica. Rio de Janeiro, Civilização Brasileira, 2001.

BANDEIRA, Luiz Alberto Moniz. O governo João Goulart. As lutas sociais no Brasil - 1961-1964. Rio de Janeiro, Civilização Brasileira, 1977.

BENEVIDES, Maria Victória. O PTB e o trabalhismo. Partido e sindicato em São Paulo (19451964). São Paulo, CEDEC/Brasiliense, 1989.

BENEVIDES, Maria Vitória. A UDN e o udenismo. Ambigüidades do liberalismo brasileiro (19451965). São Paulo, Paz e Terra, 1981.

BENEVIDES, Maria Vitória. O governo Kubitschek: desenvolvimento econômico e estabilidade política. Rio de Janeiro, Paz e Terra, 1979.

CARVAlHO, José Murilo. Cidadania no Brasil. O longo caminho. Rio de Janeiro, Civilização Brasileira, 2004.

D'ARAUJO, Maria Celina. Sindicatos, carisma e poder: o PTB de 1945-65. Rio de Janeiro, FGV, 1996.

D'ARAUJO, Maria Celina. O segundo governo Vargas 1951-1954. Rio de Janeiro, Zahar, 1982.

DELGADO, Lucília de Almeida Neves. PTB: do getulismo ao reformismo. 1945-1964. São Paulo, Marco Zero, 1989.

DREIFUSS, René A. 1964: a conquista do Estado. Ação política, poder e golpe de classe. Petrópolis, Vozes, 1981.

DULCI, Otávio. A UDN e o anti-populismo no Brasil. Belo Horizonte, Editora da UFMG, 1986.

FERREIRA, Jorge. João Goulart. Uma biografia. Rio de Janeiro, Civilização Brasileira, 2011.

FERREIRA, Jorge. O imaginário trabalhista. Getulismo, PTB e cultura política popular. Rio de Janeiro, Civilização Brasileira, 2005.

FERREIRA, Jorge. O populismo e sua história. Debate e crítica. Rio de Janeiro, Civilização Brasileira, 2001.

FIGUEIREDO, Argelina. Democracia ou reformas? Alternativas democráticas à crise política: 1961-1964. São Paulo, Paz e Terra, 1993.

GOMES, Angela de Castro. "Questão social e historiografia no Brasil, do pós-1980: notas para um debate. Estudos Históricos, vol. 2, n. 34, 2004.

GOMES, Angela de Castro. A política brasileira em busca da modernidade: na fronteira entre o pública e o privado. In SCHWARCZ, Lilia M. (org.). História da vida privada no Brasil. Contrastes da intimidade contemporânea. São Paulo, Companhia das Letras, 1998, volume 4.

GORENDER, Jacob. Era o golpe de 64 inevitável? TOLEDO, Caio Navarro de (ORG.). 1964. Visões críticas do golpe. Democracia e reformas no populismo. Campinas, Editora da Unicamp, 1997.

HIPPOLITO, Lúcia P. De raposas e reformistas: o PSD e a experiência democrática brasileira (1945-64). Rio de Janeiro, Paz e Terra, 1985.

IANNI, Octávio. O populismo na América Latina. Rio de Janeiro, Civilização Brasileira, 1968.

LAVAREDA, Antônio. A democracia nas urnas. O processo partidário-eleitoral brasileiro (19451964). Rio de Janeiro, Iuperj/Revan, 1999. 


\section{A experiência liberal-democrática no Brasil (1946-1964)}

MOTTA, Rodrigo Patto Sá. Em guarda contra o "perigo vermelho". O anticomunismo no Brasil (1917-1964. São Paulo, Perspectiva/FAPESP, 2002.

MOTTA, Rodrigo Patto Sá. João Goulart e a mobilização anticomunista de 1961-64. In FERREIRA, Marieta de Moraes (coord.). João Goulart. Entre a memória e a história. Rio de Janeiro, FGV, 2006, p. 143.

OLIVEIRA, Lúcia Lippi. O Partido Social Democrático. In FLEISCHER, David. (org). Os Partidos Políticos no Brasil. Brasília, Editora UNB, vol I, 1981.

SANTOS, Wanderley Guilherme dos. Sessenta e quatro: anatomia da crise. Rio de Janeiro, Vértice, 1986.

SOARES, Gláucio Ary Dillon. A democracia interrompida. Rio de Janeiro, FGV, 2001.

SOUZA, Maria do Carmo Campello. Estado e partidos políticos no Brasil (1930-1964). São Paulo, Alfa-Ômega, 1976.

WEFFORT, Francisco. O populismo na política brasileira. Rio de Janeiro, Paz e Terra, 1978. 